\title{
Pronitridine and Nitrapyrin With Anhydrous Ammonia for Corn
}

\author{
Gurbir Singh $^{1} \&$ Kelly A. Nelson ${ }^{1}$ \\ ${ }^{1}$ Division of Plant Sciences, University of Missouri, Novelty, MO, USA \\ Correspondence: Gurbir Singh, Lee Greenley Jr. Memorial Research Center, Division of Plant Sciences, \\ University of Missouri, Novelty, MO 63460, USA. Tel: 1-660-739-4410. E-mail: singhgu@missouri.edu
}

Received: December 20, 2018

Accepted: January 18, 2019 Online Published: March 15, 2019

doi:10.5539/jas.v11n4p13

URL: https://doi.org/10.5539/jas.v11n4p13

\begin{abstract}
Nitrogen $(\mathrm{N})$ losses due to leaching, denitrification and/or ammonia volatilization are of utmost concerns since they reduce farm profitability and adversely affect environmental quality. To combat these $\mathrm{N}$ losses, a new nitrification inhibitor (NI), pronitridine, can be used to slow down the nitrification process. A two-year (2014, 2015) field experiment was conducted to evaluate the effectiveness of pronitridine at different rates $(9.4,18.7$, and $28.1 \mathrm{~L} \mathrm{ha}^{-1}$ ) with anhydrous ammonia (AA) at $112 \mathrm{~kg} \mathrm{~N} \mathrm{ha}^{-1}$ when applied in the fall or pre-plant on claypan soils in northeast Missouri. Using pronitridine at $9.4 \mathrm{~L} \mathrm{ha}^{-1}$ with AA in the fall during a low yielding year (2015) increased corn grain yield 7\% compared to AA + nitrapyrin $\left(2.3 \mathrm{~L} \mathrm{ha}^{-1}\right)$. Agronomic efficiency and yields were greatest with pronitridine at $9.4 \mathrm{~L} \mathrm{ha}^{-1}$ than $\mathrm{AA}+$ nitrapyrin. Grain N removal was highest for AA + pronitridine at $18.7 \mathrm{~L} \mathrm{ha}^{-1}$ compared to AA + nitrapyrin. Pre-plant application of AA + pronitridine at $9.4 \mathrm{~L} \mathrm{ha}^{-1}$ increased grain starch content compared to AA without NI, but it was not significantly different from AA + nitrapyrin. Results indicated that pronitridine was effective in increasing yields when applied in the fall and was similar to other NI's when applied pre-plant in the spring.
\end{abstract}

Keywords: corn, enhanced efficiency fertilizer, nitrification inhibitor, nitrapyrin, Instinct, N-serve, N management, in-season best management practice

\section{Introduction}

A best management practice (BMP) for reducing the environmental impact of $\mathrm{N}$ loss through denitrification, volatilization and leaching while sustaining or increasing corn yields includes the use of a nitrification inhibitor (NI) (Abalos, Jeffery, Sanz-Cobena, Guardia, \& Vallejo, 2014; Malhi, Grant, Johnston, \& Gill, 2001). Nitrification inhibitor slows down the conversion of ammonium to nitrate, thereby potentially reducing nitrate-N $\left(\mathrm{NO}_{3}-\mathrm{N}\right)$ losses via leaching or denitrification (Decock, 2014; Wolt, 2004). Nitrapyrin [2-Chloro-6-(trichloromethyl)pyridine] is the most commonly used NI sold as N-Serve ${ }^{\mathbb{B}}$ (NS) and Instinct ${ }^{\mathbb{B}}$ (I), by Dow AgroSciences, Indianapolis, IN. Nitrapyrin (NS) is generally added to AA for fall $\mathrm{N}$ applications to prevent subsurface $\mathrm{N}$ leaching losses (Randall, Vetsch, \& Huffman, 2003), whereas a micro-encapsulated liquid version of nitrapyrin (I) is used with urea and urea ammonium nitrate (UAN) application.

Extensive research has been conducted on NI's with several reviews on the effects of NI's on the reduction of N loss and the impact on crop production (Aulakh, Rennie, \& Paul, 1984; Burzaco, Ciampitti, \& Vyn, 2014; Cerrato \& Blackmer, 1990; Cook et al., 2015; Fisk, Maccarone, Barton, \& Murphy, 2015; Frame, 2017; Prasad, 1995; Wolt, 2004). Research on NI's has shown positive, neutral, or negative effects on grain yield (Quemada, Baranski, Nobel-de Lange, Vallejo, \& Cooper, 2013; Wolt, 2004). Randall and Vetsch (2005) reported that the addition of nitrapyrin to fall-applied AA decreased average flow-normalized $\mathrm{NO}_{3}-\mathrm{N}$ leaching losses by $10 \%$ compared to fall-applied AA without nitrapyrin. Similarly, $\mathrm{N}_{2} \mathrm{O}$ emissions decreased $19-27 \%$ when nitrapyrin was used with UAN in Indiana (Omonode \& Vyn, 2013). The addition of nitrapyrin to AA increased corn grain yield $0.94 \mathrm{Mg} \mathrm{ha}^{-1}$ compared to treatments without nitrapyrin (Vetsch \& Randall, 2004). In contrast, Stehouwer and Johnson (1990) found no beneficial effect of nitrapyrin on corn grain yield for spring-applied $\mathrm{N}$ in Ohio. In Minnesota, grain yield increased with AA + nitrapyrin in one year out of six (Randall \& Vetsch, 2005). In contrast, Blackmer and Sanchez (1988) reported corn grain yields were reduced when nitrapyrin was added and they reported that nitrapyrin increased the susceptibility of plants to moisture stress and induced ammonia toxicity to the plants. 
Nitrification inhibitors play important role for managing $\mathrm{N}$ losses in claypan soils of north central and eastern Missouri (Habibullah, Nelson, \& Motavalli, 2018; Nelson, 2018). In Missouri, NI's have been evaluated with N fertilizers for their effect on placement, timing, rates, tillage, $\mathrm{N}$ losses in water, $\mathrm{N}_{2} \mathrm{O}$ emissions, corn grain quality and yield (Habibullah, Nelson, \& Motavalli, 2017; Hanson, Maledy, \& Jentes, 1987; Nash, Nelson, \& Motavalli, 2013a, 2013b; Nash, Motavalli, \& Nelson, 2012; Nelson, 2018; Nelson, Paniagua, \& Motavalli, 2009). A new NI, pronitridine (CAS RN 1373256-33-7, Centuro ${ }^{\mathrm{TM}}$, Koch Agronomic Services, Wichita, KS), was recently developed to enhance the efficiency of applied $\mathrm{N}$ fertilizer by inhibiting the nitrification process and reducing $\mathrm{N}$ losses through leaching or denitrification (Gabrielson \& Epling, 2016; Nelson, 2018; Vetsch \& Schwab, 2014). In Minnesota, UAN was supplemented with three NI's treatments (two rates of pronitridine and one of nitrapyrin) to evaluate the effects on corn grain yield (Vetsch \& Schwab, 2014). During a wet year, the lowest corn yields were observed with UAN in the absence of a NI. Nelson (2018) reported that UAN plus pronitridine applied pre-emergence had corn grain yields similar to UAN plus nitrapyrin in Missouri. In California, a significant reduction in $\mathrm{N}_{2} \mathrm{O}$ emissions from UAN plus pronitridine treatments was found when compared to other treatments including calcium nitrate and AA with or without NI's (Waterhouse, Wade, Horwath, \& Burger, 2017); however, no improvement in corn yields or $\mathrm{N}$ use efficiency was observed. There is lack of research on the use of pronitridine with AA application on corn in the Midwest US. Therefore, the objective of this research was to evaluate the effectiveness of pronitridine and nitrapyrin applied in the fall or spring (pre-plant) on corn grain yield, $\mathrm{N}$ uptake, and quality.

\section{Materials and Methods}

\subsection{Study Location and Experimental Design}

The experiment was conducted at the University of Missouri Greenley Research Center near Novelty, MO $\left(40^{\circ} 1^{\prime} 41.4^{\prime \prime} \mathrm{N}, 92^{\circ} 11^{\prime} 18.6^{\prime \prime} \mathrm{W}\right)$ in 2014 and 2015 . The soil was a Putnam silt loam (fine, smectitic, mesic, Vertic Albaqualfs). These soils typically have a clay layer approximately $45-50 \mathrm{~cm}$ below the soil surface which causes poor internal drainage (Nelson \& Smoot, 2012), and subsequently results in gaseous N loss (Nash et al., 2012). Precipitation was collected on-site (Table 1) throughout the growing season using an automated weather station (Campbell Scientific, Inc., Logan, UT).

Table 1. Monthly precipitation average (10-year) and precipitation during the growing season at Novelty, Missouri in 2014 and 2015

\begin{tabular}{|c|c|c|c|}
\hline \multirow{2}{*}{ Month } & \multicolumn{3}{|c|}{ Precipitation } \\
\hline & 10 -year average ${ }^{\dagger}$ & 2014 & 2015 \\
\hline & --- & - & ---'- \\
\hline April & 139 & 106 & 71 \\
\hline May & 153 & 26 & 119 \\
\hline June & 94 & 225 & 322 \\
\hline July & 59 & 51 & 257 \\
\hline August & 62 & 164 & 106 \\
\hline September & 86 & 175 & 35 \\
\hline Total & 612 & 747 & 911 \\
\hline
\end{tabular}

Note. ${ }^{\dagger}$ Averaged from 2002 to 2013.

The study was arranged in a randomized complete block design with six replications in plots 3 by $15 \mathrm{~m}$. This research was arranged as two-factor experiment with NI treatments [pronitridine (Centuro ${ }^{\mathrm{TM}}$, Koch Agronomic Services, Wichita, KS) at $9.4 \mathrm{~L} \mathrm{ha}^{-1}, 18.8 \mathrm{~L} \mathrm{ha}^{-1}$, and $28.1 \mathrm{~L} \mathrm{ha}^{-1}$, nitrapyrin (NS) and nitrapyrin (I) at $0.5 \mathrm{~kg}$ a.i. $\mathrm{ha}^{-1}$ ] which were either fall or preplant spring applied with $112 \mathrm{~kg} \mathrm{~N} \mathrm{ha}^{-1}$ as AA. In addition to the above NI treatments, AA with UAN (32\%) at a rate equivalent to the $\mathrm{N}$ present in $9.4 \mathrm{~L} \mathrm{ha}^{-1}$ of pronitridine and a non-treated control treatment were also included in the experiment.

\subsection{Field and Crop Management}

Anhydrous ammonia was applied using a John Deere 2510 (Moline, IL) applicator. The pronitridine was injected using a separate tube on each applicator unit. The outlet was as close to the anhydrous stream as possible, i.e. 1 $\mathrm{cm}$ or less. Pronitridine contains a NI mixed into a $30 \% \mathrm{~N}$ fertilizer $\left(0.38 \mathrm{~kg} \mathrm{~N} \mathrm{~L}^{-1}\right)$ that includes slow release $\mathrm{N}$ compound. To offset $\mathrm{N}$ in the pronitridine, a treatment not receiving pronitridine received $7.9 \mathrm{~L} \mathrm{ha}^{-1}$ of UAN that 
was similar to the average $\mathrm{N}$ contribution from pronitridine. Nitrapyrin (NS) was applied using a Sidekick ${ }^{\mathrm{TM}}$ injection system (Sioux Falls, SD) while nitrapyrin (I) was applied using the same application system as pronitridine. Fall treatments were applied after the soil temperature was below $10{ }^{\circ} \mathrm{C}$ at a depth of $15 \mathrm{~cm}$. Spring pre-plant applications were done at a time consistent with local farming practices. Selected management practices are reported in Table 2.

Table 2. Selected management practices and application information in 2014 and 2015

\begin{tabular}{|c|c|c|}
\hline Field information & 2014 & 2015 \\
\hline Previous crop & Soybean & Soybean \\
\hline Tillage & No-till & No-till \\
\hline Planting date & 9 Apr. & 18 Apr. \\
\hline Hybrid & DKC 62-97VT3 & DKC 62-97VT3 \\
\hline Seeding rate (seeds ha-1) & 81,500 & 81,500 \\
\hline \multicolumn{3}{|l|}{ Fertilizer application dates } \\
\hline Fall & 28 Oct. 2013 & 7 Nov. 2014 \\
\hline Preplant & 26 Mar. & 23 Mar. \\
\hline Maintenance & 11 Apr. & 3 Apr. \\
\hline $\mathrm{N}-\mathrm{P}_{2} \mathrm{O}_{5}-\mathrm{K}_{2} \mathrm{O}\left(\mathrm{kg} \mathrm{ha}^{-1}\right)$ & $22-90-135-22 S-2 Z n$ & $18-90-90$ \\
\hline \multicolumn{3}{|l|}{ Crop protection chemicals } \\
\hline Fungicide & $\begin{array}{l}10 \text { July, Azoxystrobin }{ }^{\dagger}\left(0.12 \mathrm{~kg} \text { a.i. } \mathrm{ha}^{-1}\right)+ \\
\text { propiconazole }\left(0.10 \mathrm{~kg} \text { a.i. } \mathrm{ha}^{-1}\right)\end{array}$ & $\mathrm{NA}^{\ddagger}$ \\
\hline \multicolumn{3}{|l|}{ Herbicide } \\
\hline POST & $\begin{array}{l}6 \text { May, Acetochlor }\left(2.65 \mathrm{~kg} \text { a.i. } \mathrm{ha}^{-1}\right)+\text { atrazine } \\
\left(1.88 \mathrm{~kg} \text { a.i. ha } \mathrm{ha}^{-1}\right)+\text { glyphosate }(1.06 \mathrm{~kg} \text { a.i. } \\
\left.\mathrm{ha}^{-1}\right)+ \text { DAS }\left(0.02 \mathrm{~kg} \mathrm{~L}^{-1}\right)\end{array}$ & $\begin{array}{l}23 \text { Apr. saflufenacil at } 0.02 \mathrm{~kg} \mathrm{ha}^{-1}+\text { glyphosate } \\
\left(1.06 \mathrm{~kg} \text { a.i. } \mathrm{ha}^{-1}\right)+\text { UAN at } 2.34 \mathrm{~L} \mathrm{ha}^{-1}+\text { MSO at } \\
1 \% \mathrm{v} / \mathrm{v}\end{array}$ \\
\hline Late POST & $\begin{array}{l}11 \text { June, Glyphosate }\left(1.06 \mathrm{~kg} \text { a.i. } \mathrm{ha}^{-1}\right)+ \\
\text { topramezone }\left(0.02 \mathrm{~kg} \text { a.i. ha } \mathrm{h}^{-1}\right)+\text { atrazine }(0.25 \\
\left.\mathrm{kg} \text { a.i. ha- }{ }^{-1}\right)+ \text { DAS }\left(0.02 \mathrm{~kg} \mathrm{~L}^{-1}\right)\end{array}$ & $\begin{array}{l}10 \text { June, Glyphosate }\left(1.55 \mathrm{~kg} \text { a.i. } \mathrm{ha}^{-1}\right)+ \\
\text { mesotrione }\left(0.09 \mathrm{~kg} \text { a.i. } \mathrm{ha}^{-1}\right)+\text { DAS }\left(0.02 \mathrm{~kg} \mathrm{~L}^{-1}\right)\end{array}$ \\
\hline Harvest date & 6 Oct. & 15 Sept. \\
\hline
\end{tabular}

(2-chloro-4-(ethylamino)-6-(isopropylamino)-s-triazine); azoxystrobin, methyl (E)-2-(2-[6-(2-cyanophenoxy) pyrimidin-4-yloxy] phenyl)-3-methoxyacrylate; diammonium sulfate $\left((\mathrm{NH} 4)_{2} \mathrm{SO}_{4}\right) ;$ glyphosate, (N-(phosphonomethyl)glycine); MSO, alcohol ethoxylate, phosphatidylcholine; mesotrione (2-[4-(Methylsulfonyl)-2-nitrobenzoyl]cyclohexane-1,3-dione);

1-[[2-(2,4-dichlorophenyl)-4-propyl-1,3-dioxolan-2-yl]Methyl]-1H-1,2,4-triazole; and saflufenacil, N'-[2-chloro-4-fluoro-5-(3-methyl-2,6-dioxo-4-(trifluoromethyl)-3,6-dihydro-1(2H)-pyrimidinyl)benzoyl]-N-iso propyl-N-methylsulfamide.

$\$$ Abbreviations: DAS, Diammonium sulfate; NA, none applied; MSO, Methylated seed oil; POST, post emergence; UAN, urea ammonium nitrate.

\subsection{Data Collection}

Prior to fall $\mathrm{N}$ application, composite soil samples were taken from the plot area of each replication using an Uhland probe from four depths $(0-15,16-30,31-60$, and 61-90 cm). Collected soil samples were analyzed for soil properties given in Table 3 using standard soil testing analytical procedures for Missouri (Nathan, Stecker, \& Sun, 2012). The $0-15 \mathrm{~cm}$ deep soil samples were analyzed for $\mathrm{pH}\left(0.01 \mathrm{M} \mathrm{CaCl}_{2}\right)$, organic matter content, cation exchange capacity, available $\mathrm{P}, \mathrm{K}, \mathrm{Ca}, \mathrm{Mg}$, and gravimetric soil moisture content. Soil samples from all depths were analyzed for nitrate and exchangeable ammonium concentrations. 
Table 3. Soil properties at 0 to $15 \mathrm{~cm}$ and soil moisture content, soil nitrate $\left(\mathrm{NO}_{3}-\mathrm{N}\right)$, and ammonium $\left(\mathrm{NH}_{4}-\mathrm{N}\right)$ concentration at four depths in 2014 and 2015 at the study location

\begin{tabular}{|c|c|c|c|}
\hline Soil test information & Soil Depth & 2014 & 2015 \\
\hline & $\mathrm{cm}$ & & \\
\hline $\mathrm{pH}_{\mathrm{s}}\left(0.02 \mathrm{M} \mathrm{CaCl}_{2}\right)$ & $0-15$ & $6.0 \pm 0.2^{\dagger}$ & $6.6 \pm 0.2$ \\
\hline Bray I-P $\left(\mathrm{kg} \mathrm{ha}^{-1}\right)$ & $0-15$ & $47.1 \pm 7.4$ & $45 \pm 25$ \\
\hline \multicolumn{4}{|l|}{ Exchangeable $\left(1 \mathrm{M} \mathrm{NH}_{4} \mathrm{Cl}\right)$} \\
\hline $\mathrm{K}\left(\mathrm{kg} \mathrm{ha}^{-1}\right)$ & $0-15$ & $355 \pm 39$ & $253 \pm 56$ \\
\hline $\mathrm{Ca}\left(\mathrm{kg} \mathrm{ha}^{-1}\right)$ & $0-15$ & $4483 \pm 493$ & $5201 \pm 473$ \\
\hline $\operatorname{Mg}\left(\mathrm{kg} \mathrm{ha}^{-1}\right)$ & $0-15$ & $562 \pm 98$ & $527 \pm 67$ \\
\hline $\mathrm{CEC}\left(\mathrm{cmol}_{\mathrm{c}} \mathrm{kg}^{-1}\right)$ & $0-15$ & $14.4 \pm 1.9$ & $14.3 \pm 0.9$ \\
\hline $\mathrm{OM}\left(\mathrm{g} \mathrm{kg}^{-1}\right)$ & $0-15$ & $24.1 \pm 2.3$ & $29.2 \pm 4.2$ \\
\hline \multirow[t]{4}{*}{ Soil moisture content $(\%)$} & $0-15$ & $20.3 \pm 0.6$ & $20.5 \pm 0.6$ \\
\hline & $16-30$ & $23.0 \pm 2.1$ & $23.8 \pm 1.9$ \\
\hline & $31-60$ & $26.8 \pm 3.4$ & $28.0 \pm 3.6$ \\
\hline & $61-90$ & $22.7 \pm 2.8$ & $23.7 \pm 3.1$ \\
\hline \multirow[t]{4}{*}{$\mathrm{NO}_{3}-\mathrm{N}\left(\mathrm{mg} \mathrm{kg}^{-1}\right)$} & $0-15$ & $4.9 \pm 0.9$ & $8.1 \pm 2.4$ \\
\hline & $16-30$ & $5.0 \pm 0.7$ & $2.0 \pm 0.6$ \\
\hline & $31-60$ & $2.5 \pm 0.7$ & $0.6 \pm 0.3$ \\
\hline & $61-90$ & $3.1 \pm 2.2$ & $0.4 \pm 0.1$ \\
\hline \multirow[t]{4}{*}{$\mathrm{NH}_{4}-\mathrm{N}\left(\mathrm{mg} \mathrm{kg}^{-1}\right)$} & $0-15$ & $5.7 \pm 1.1$ & $3.9 \pm 1.6$ \\
\hline & $16-30$ & $6.0 \pm 2.1$ & $3.2 \pm 0.3$ \\
\hline & $31-60$ & $6.9 \pm 2.3$ & $5.1 \pm 0.9$ \\
\hline & $61-90$ & $7.0 \pm 1.2$ & $2.8 \pm 0.5$ \\
\hline
\end{tabular}

Note. ${ }^{\dagger}$ Standard deviation.

$\$$ Abbreviations: CEC, cation exchange capacity; OM, organic matter.

A Minolta SPAD-502 meter (Konica Minolta Optics, Inc., Aurora, IL) was used to collect chlorophyll meter readings from 10 ear leaves plot $^{-1}$ at the VT growth stage of corn (Abendroth, Elmore, Boyer, \& Marlay, 2011). The SPAD chlorophyll meter readings have been shown to be strongly related to chlorophyll concentration or greenness of plant leaves (Markwell et al., 1995; Scharf et al., 2006). To determine ear leaf N concentration, 10 ear leaves plot $^{-1}$ were collected at R1 growth stage, dried, and analyzed for total $\mathrm{N}$ concentration by combustion using a total C:N analyzer (LECO, TruSPEC CN Analyzer, St. Joseph, MI).

Plant populations were determined before harvest from one row extending the entire length of the plot. Grain yield, moisture, and test weight were determined using a Wintersteiger Delta (Salt Lake City, UT) equipped with a HarvestMaster GrainGage (SBDS800, Juniper Systems Inc., Logan, UT). Grain yields were adjusted to $150 \mathrm{~g}$ $\mathrm{kg}^{-1}$ prior to statistical analysis. Collected grain samples were analyzed for $\mathrm{N}$ concentration by combustion using a total C:N analyzer (LECO, TruSPEC CN Analyzer, St. Joseph, MI). Grain samples were also analyzed for protein, oil, and starch concentration with a Foss Infratec 1241 Grain Analyzer (Eden Prairie, MN). Agronomic efficiency was calculated as $\left(\mathrm{Y}-\mathrm{Y}_{0}\right) / \mathrm{F}$ where $\mathrm{Y}=$ grain yield of the harvested portion of corn with nutrient applied, $\mathrm{Y}_{0}=$ grain yield of corn with no nutrient applied, and $\mathrm{F}=$ amount of nutrient applied to determine the short-term impact of $\mathrm{N}$ on productivity (Fixen et al., 2015). Additionally, the yield increase for NI treatments was calculated by comparing NI treatments with that of AA with UAN.

\subsection{Statistical Analysis}

Prior to data analysis, all variables were subjected to normality analysis using the Univariate procedure in SAS (SAS, 2014). The Glimmix procedure in SAS was used for analysis. The fixed factor in the statistical model was NI treatments, timing of $\mathrm{N}$ applications and year whereas replications were considered as random factors. The three-way interaction between fixed factors was not statistically significant for any of the dependent variables and there was no significant difference in the timing of the application of the treatments. Therefore, timing of $\mathrm{N}$ application was dropped as a fixed factor and data were analyzed separately for fall and spring applied treatments. The T-grouping for least square means $(P=0.1)$ was used to determine differences among NI treatments and years. 


\section{Results and Discussion}

\subsection{Growing Season Precipitation and Its Effects on Corn Yield}

The total precipitation for 2014 and 2015 was 135 and $299 \mathrm{~mm}$ higher, respectively, than the 10-year average precipitation received during the growing season from April to September (Table 1). June was the wettest month during the two growing seasons. June and July of 2015 received 228- and 198-mm higher rainfall compared to the 10-year average monthly precipitation. In 2015, wet conditions during the corn growing season probably contributed to lower overall yields compared to 2014 (Figure 1). Claypan soils, if not drained during wet years, can result in waterlogged conditions causing $\mathrm{N}$ loss (runoff or denitrification), and reduced $\mathrm{N}$ availability to the cash crop (Kaur, Zurweller, Nelson, Motavalli, \& Dudenhoeffer, 2017). A reduction in N availability during wet years can reduce corn grain yield (Figure 1).

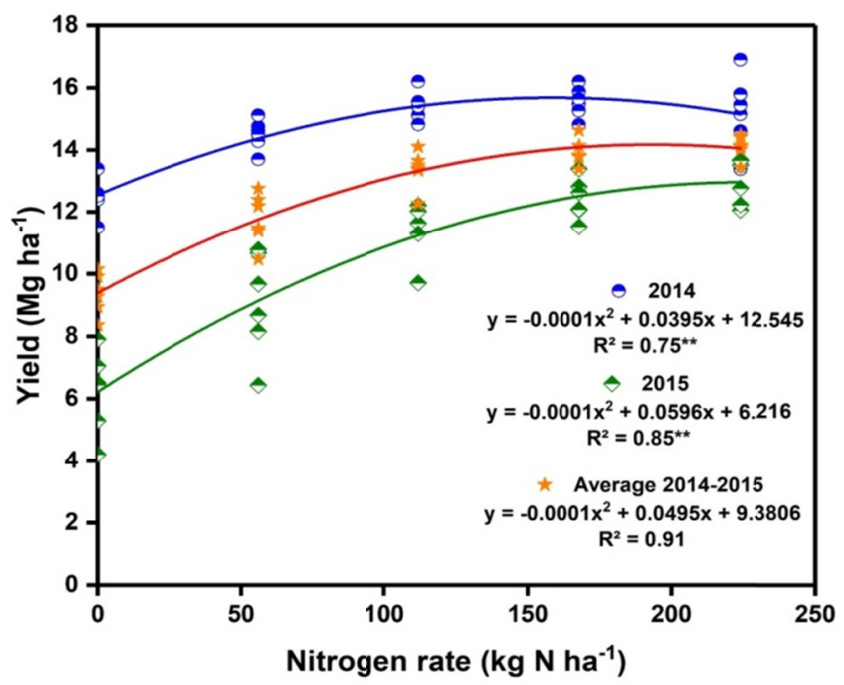

Figure 1. Corn yield response to $\mathrm{N}$ rates applied in the spring in the absence of a nitrification inhibitor in 2014 (blue line with circles), 2015 (green line with diamonds) and the average from 2014-2015 (orange line with stars). Individual points at each nitrogen rate represents six replicates in each year

\subsection{Fall N Application}

\subsubsection{Chlorophyll Meter Readings}

The chlorophyll meter readings for fall $\mathrm{N}$ applications were affected by an interaction between year and NI (Tables 4 and 6). Many studies have shown a positive correlation between chlorophyll meter readings and $\mathrm{N}$ fertilizer application rates (Schepers et al., 1992; Costa et al., 2001). The chlorophyll meter reading in the nontreated control in 2014 was 15.53 SPAD unit's greater than 2015. The 2015 growing season was comparatively wetter than 2014 (Table 1). The excessive soil moisture due to wet growing season conditions may have adversely affected plant growth and consequently, reduced $\mathrm{N}$ uptake due to restricted root growth and lowered $\mathrm{N}$ availability due to $\mathrm{N}$ denitrification loss (Kisaakye et al., 2015; Nash et al., 2015; Kaur et al., 2018). Reduction in $\mathrm{N}$ uptake under wet soil conditions might have resulted in lower chlorophyll meter readings and earleaf $\mathrm{N}$ concentration in our study (Table 6).

Table 4. Probability values (p-values) and numerator degrees of freedom (df) associated with the sources of variation in the statistical analysis of nitrification inhibitor treatments when $\mathrm{N}$ was applied in fall at $112 \mathrm{~kg} \mathrm{~N} \mathrm{ha}^{-1}$

\begin{tabular}{|c|c|c|c|c|c|c|c|c|c|c|c|c|c|c|}
\hline Source & $\begin{array}{l}\text { d } \\
\text { f }\end{array}$ & $\begin{array}{l}\text { Chlorophyll } \\
\text { meter }\end{array}$ & $\begin{array}{l}\text { Ear } \\
\text { leaf } N\end{array}$ & Population & Moisture & $\begin{array}{l}\text { Test } \\
\text { weight }\end{array}$ & Yield & $\begin{array}{l}\text { Yield } \\
\text { increase }^{\dagger}\end{array}$ & Grain N & $\begin{array}{l}\text { Grain } N \\
\text { removal }\end{array}$ & $\begin{array}{l}\text { Agronomic } \\
\text { efficiency }\end{array}$ & Protein & Oil & Starch \\
\hline & & & & & & & & & & & & & & \\
\hline Nitrification inhibitor & 6 & $<0.0001$ & $<0.0001$ & 0.0923 & 0.0863 & $<0.0001$ & $<0.0001$ & 0.0990 & $<0.0001$ & $<0.0001$ & 0.0985 & $<0.0001$ & 0.9469 & 0.2919 \\
\hline Year & 1 & 0.0003 & $<0.0001$ & 0.3628 & $<0.0001$ & $<0.0001$ & $<0.0001$ & 0.8068 & $<0.0001$ & $<0.0001$ & $<0.0001$ & $<0.0001$ & 0.0751 & $<0.0001$ \\
\hline Nitrification inhibitor*Year & 6 & $<0.0001$ & 0.0005 & 0.4566 & 0.7609 & 0.5947 & $<0.0001$ & 0.2056 & 0.0880 & 0.8925 & 0.2074 & 0.0340 & 0.0327 & 0.0176 \\
\hline
\end{tabular}

Note. ${ }^{\dagger}$ Yield increase for NI treatments was calculated by comparing NI treatments with that of AA with UAN. 
Table 5. Probability values (p-values) and numerator degrees of freedom (df) associated with the sources of variation in the statistical analysis of nitrification inhibitor treatments when $\mathrm{N}$ was applied in spring (pre-plant) at $112 \mathrm{~kg} \mathrm{~N} \mathrm{ha}^{-1}$

\begin{tabular}{|c|c|c|c|c|c|c|c|c|c|c|c|c|c|c|}
\hline Source of variation & df & $\begin{array}{l}\text { Chlorophyll } \\
\text { meter }\end{array}$ & $\begin{array}{l}\text { Ear } \\
\text { leaf } N\end{array}$ & Population & Moisture & $\begin{array}{l}\text { Test } \\
\text { weight }\end{array}$ & Yield & $\begin{array}{l}\text { Yield } \\
\text { increase }^{\dagger}\end{array}$ & Grain N & $\begin{array}{l}\text { Grain N } \\
\text { removal }\end{array}$ & $\begin{array}{l}\text { Agronomic } \\
\text { efficiency }\end{array}$ & Protein & Oil & Starch \\
\hline & & p-values & & & & & & & & & & & & \\
\hline Nitrification inhibitor & 6 & $<0.0001$ & $<0.0001$ & 0.3290 & 0.0054 & 0.3670 & $<0.0001$ & 0.3063 & $<0.0001$ & $<0.0001$ & 0.3369 & $<0.0001$ & 0.4464 & 0.0040 \\
\hline Year & 1 & $<0.0001$ & $<0.0001$ & 0.1388 & $<0.0001$ & 0.0002 & $<0.0001$ & 0.9803 & $<0.0001$ & $<0.0001$ & 0.0035 & $<0.0001$ & 0.1047 & $<0.0001$ \\
\hline Nitrification inhibitor*Year & 6 & 0.0084 & 0.0549 & 0.6270 & 0.6933 & 0.4751 & 0.1184 & 0.8768 & 0.2255 & 0.7040 & 0.9529 & 0.0014 & 0.4672 & 0.6703 \\
\hline
\end{tabular}

Note. ${ }^{\dagger}$ Yield increase for NI treatments was calculated by comparing NI treatments with that of AA with UAN.

Table 6. Corn response to nitrification inhibitor with anhydrous ammonia when $\mathrm{N}$ amount was $112 \mathrm{~kg} \mathrm{~N} \mathrm{ha}^{-1}(\alpha=$ 0.1 ). Results of significant interaction between nitrification inhibitor treatment and year

\begin{tabular}{|c|c|c|c|c|c|c|c|c|c|c|c|c|}
\hline \multirow{3}{*}{$\begin{array}{l}\text { Nitrification } \\
\text { Inhibitor }\end{array}$} & \multirow{3}{*}{$\begin{array}{l}\text { Application } \\
\text { Rates }\end{array}$} & \multirow{3}{*}{ Year } & \multicolumn{7}{|c|}{ Fall Application } & \multicolumn{3}{|c|}{ Spring Application } \\
\hline & & & \multirow{2}{*}{$\begin{array}{l}\text { Chlorophyll } \\
\text { meter }\end{array}$} & \multirow{2}{*}{$\begin{array}{l}\text { Ear } \\
\text { leaf } N\end{array}$} & \multicolumn{5}{|c|}{ Corn Grain Parameters } & \multirow{2}{*}{$\begin{array}{l}\text { Chlorophyll } \\
\text { meter }\end{array}$} & \multirow{2}{*}{$\begin{array}{l}\text { Ear } \\
\text { leaf } N\end{array}$} & \multirow{2}{*}{$\begin{array}{l}\text { Grain } \\
\text { Protein }\end{array}$} \\
\hline & & & & & Yield & Grain N & Protein & Oil & Starch & & & \\
\hline & $\mathrm{L} \mathrm{ha}^{-1}$ & & SPAD units & $\mathrm{g} \mathrm{kg}^{-1}$ & $\mathrm{Mg} \mathrm{ha}^{-1}$ & - - - & $\mathrm{g} \mathrm{kg}^{-}$ & $-\ldots$ & --.----- & SPAD units & ---- g k & $g^{-1}---$ \\
\hline \multirow[t]{2}{*}{ Pronitridine } & 9.4 & 2014 & $57.68 \mathrm{abc} c^{\S}$ & $32.43 \mathrm{a}$ & $15.77 \mathrm{a}$ & $13.02 \mathrm{a}$ & $83 a$ & $38 \mathrm{a}$ & $728 \mathrm{f}$ & $60.03 \mathrm{a}$ & $31.16 \mathrm{a}$ & $82 b$ \\
\hline & 9.4 & 2015 & $54.67 \mathrm{cde}$ & $25.87 \mathrm{~cd}$ & $11.52 \mathrm{~cd}$ & $10.00 \mathrm{bcd}$ & $68 \mathrm{de}$ & $32 \mathrm{c}$ & $748 \mathrm{a}$ & $54.77 \mathrm{~d}$ & $25.52 \mathrm{bcd}$ & $70 \mathrm{de}$ \\
\hline \multirow[t]{2}{*}{ Pronitridine } & 18.7 & 2014 & $58.82 \mathrm{ab}$ & $32.59 \mathrm{a}$ & $15.52 \mathrm{a}$ & $13.40 \mathrm{a}$ & $83 a$ & $37 \mathrm{ab}$ & $731 \mathrm{ef}$ & $58.55 \mathrm{ab}$ & $32.43 \mathrm{a}$ & $84 a$ \\
\hline & 18.7 & 2015 & 55.93 bcde & $26.99 b c$ & $11.11 \mathrm{cde}$ & $10.58 \mathrm{bc}$ & $73 b$ & $35 \mathrm{~b}$ & $740 \mathrm{bc}$ & $51.60 \mathrm{e}$ & $25.25 \mathrm{bcd}$ & $72 \mathrm{~cd}$ \\
\hline \multirow[t]{2}{*}{ Pronitridine } & 28.1 & 2014 & $58.40 \mathrm{abc}$ & $32.80 \mathrm{a}$ & $15.43 \mathrm{a}$ & $12.79 \mathrm{a}$ & $82 a$ & $36 \mathrm{ab}$ & 734de & $58.03 \mathrm{abc}$ & $32.44 \mathrm{a}$ & $83 \mathrm{ab}$ \\
\hline & 28.1 & 2015 & $53.23 \mathrm{ef}$ & $26.8 \mathrm{bc}$ & $10.37 \mathrm{e}$ & $10.09 \mathrm{bcd}$ & $70 \mathrm{bcd}$ & $35 \mathrm{~b}$ & $741 b$ & $53.00 \mathrm{de}$ & $23.76 \mathrm{~d}$ & 70de \\
\hline \multirow[t]{2}{*}{ 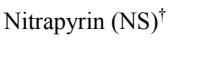 } & 2.3 & 2014 & $59.88 \mathrm{a}$ & $32.97 \mathrm{a}$ & $15.25 \mathrm{a}$ & $12.79 \mathrm{a}$ & $81 \mathrm{a}$ & $35 b$ & $735 \mathrm{cde}$ & $58.48 \mathrm{ab}$ & $32.71 \mathrm{a}$ & $81 b$ \\
\hline & 2.3 & 2015 & $51.25 \mathrm{f}$ & $24.54 \mathrm{~d}$ & $10.78 \mathrm{e}$ & $9.90 \mathrm{cde}$ & $71 \mathrm{bcd}$ & $35 b$ & $740 \mathrm{bc}$ & $54.12 \mathrm{de}$ & $25.88 \mathrm{bc}$ & $72 \mathrm{~cd}$ \\
\hline \multirow[t]{2}{*}{ Nitrapyrin (I) } & 2.6 & 2014 & $59.90 \mathrm{a}$ & $32.88 \mathrm{a}$ & $15.21 \mathrm{a}$ & $13.03 \mathrm{a}$ & $82 a$ & $35 \mathrm{~b}$ & 734de & $59.95 \mathrm{a}$ & $31.82 \mathrm{a}$ & $80 \mathrm{~b}$ \\
\hline & 2.6 & 2015 & $56.28 \mathrm{abcd}$ & $28.32 b$ & $11.84 \mathrm{bc}$ & $9.63 \mathrm{de}$ & $72 b$ & $36 a b$ & $739 \mathrm{bcd}$ & $55.82 \mathrm{bcd}$ & $26.77 b$ & $74 \mathrm{c}$ \\
\hline \multirow[t]{2}{*}{ AA with $\mathrm{UAN}^{\ddagger}$} & 7.9 & 2014 & $58.82 \mathrm{ab}$ & $32.59 \mathrm{a}$ & $15.55 \mathrm{a}$ & $12.81 \mathrm{a}$ & $80 \mathrm{a}$ & $35 \mathrm{~b}$ & $735 \mathrm{cde}$ & $59.92 \mathrm{a}$ & $31.63 \mathrm{a}$ & $85 \mathrm{a}$ \\
\hline & 7.9 & 2015 & $54.87 \mathrm{cde}$ & $27.37 \mathrm{bc}$ & $11.48 \mathrm{~cd}$ & $10.46 b c$ & $71 \mathrm{bc}$ & $35 b$ & $743 \mathrm{ab}$ & $55.52 \mathrm{bcd}$ & $24.63 \mathrm{~cd}$ & $74 \mathrm{c}$ \\
\hline \multirow[t]{2}{*}{ Non-treated Control } & & 2014 & $54.55 \mathrm{def}$ & $28.53 b$ & $12.52 \mathrm{~b}$ & $10.73 b$ & $68 \mathrm{~cd}$ & $36 \mathrm{ab}$ & $740 \mathrm{bc}$ & $55.28 \mathrm{~cd}$ & $27.12 b$ & $68 \mathrm{ef}$ \\
\hline & & 2015 & $39.02 \mathrm{~g}$ & $15.45 \mathrm{e}$ & $5.08 \mathrm{f}$ & $9.26 \mathrm{e}$ & $64 \mathrm{e}$ & $36 \mathrm{ab}$ & $743 \mathrm{ab}$ & $41.63 \mathrm{f}$ & $17.14 \mathrm{e}$ & $65 f$ \\
\hline
\end{tabular}

Note. ${ }^{\dagger}$ Nitrapyrin was applied as N-serve (NS) or Instinct (I).

$\$$ UAN $(32 \%)$ is equivalent to $9.4 \mathrm{~L} \mathrm{ha}^{-1}$ Pronitridine.

${ }^{\S}$ Within a column and a given factor, means followed by the same letter are not statistically different $(\alpha=0.1)$.

All NI treatments had significantly higher chlorophyll meter readings than the non-treated control in both years due to higher $\mathrm{N}$ availability and $\mathrm{N}$ uptake by corn plants with NI treatments than the non-treated control which received no $\mathrm{N}$ fertilizer application. No significant differences were observed between pronitridine applied at 9.4 18.7 or $28.1 \mathrm{~L} \mathrm{ha}^{-1}$, nitrapyrin (NS or I), and AA with UAN (32\%) in 2014. In 2015, use of nitrapyrin (I) resulted in chlorophyll meter readings that were 3.05 and 5.03 SPAD unit's higher than pronitridine at $28.1 \mathrm{~L} \mathrm{ha}^{-1}$ and nitrapyrin (NS), respectively (Table 6). Similarly, Nelson (2018) did not find any differences between the pronitridine and nitrapyrin when used with UAN at 67 and $135 \mathrm{~kg} \mathrm{~N} \mathrm{ha}^{-1}$. However, increasing the $\mathrm{N}$ application rate to $202 \mathrm{~kg} \mathrm{~N} \mathrm{ha}^{-1}$ resulted into higher chlorophyll meter readings with nitrapyrin (I) than pronitridine at $9.4 \mathrm{~L}$ $\mathrm{ha}^{-1}$. Increasing the application rate of pronitridine in 2015 did not result in any differences in chlorophyll meter readings. Use of AA with UAN had chlorophyll meter reading that were 3.62 SPAD unit's higher than nitrapyrin (NS) applied in 2015. Use of nitrapyrin (I) and pronitridine at 9.4 or $18.7 \mathrm{~L} \mathrm{ha}^{-1}$ showed no significant differences between years for chlorophyll meter readings. The nitrapyrin (NS), AA with UAN, and pronitridine at 28.1 $\mathrm{L} \mathrm{ha}^{-1}$ treatments had chlorophyll meter reading that were 8.63, 3.95, and 5.17 SPAD unit's higher in 2014 compared to 2015 , respectively.

\subsubsection{Ear Leaf N Concentration}

The ear leaf $\mathrm{N}$ concentration due to fall $\mathrm{N}$ applications was affected by the NI, year, and their interaction (Tables 4 and 6). Like chlorophyll meter readings, all NI treatments had significantly higher ear leaf $\mathrm{N}$ concentration than the non-treated control in each year, which was possibly due to higher $\mathrm{N}$ availability for uptake by plants in

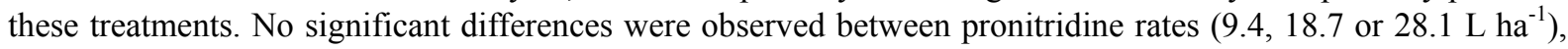
nitrapyrin (NS or I), and AA with UAN in 2014. Ear leaf N concentration was similar among different rates of 
pronitridine in both years. Nitrapyrin (I) had $2.45 \mathrm{~g} \mathrm{~kg}^{-1}$ greater ear leaf $\mathrm{N}$ concentration than pronitridine at 9.4 $\mathrm{L} \mathrm{ha}^{-1}$ in 2015. Nitrapyrin (NS) had significantly lower ear leaf $\mathrm{N}$ concentration than all other NI except pronitridine at $9.4 \mathrm{~L} \mathrm{ha}^{-1}$ and the non-treated control in 2015. In general, ear leaf $\mathrm{N}$ concentrations of all treatments were significantly higher in 2014 than 2015. The non-treated control in 2014 had $13.8 \mathrm{~g} \mathrm{~kg}^{-1} \mathrm{higher}$ ear leaf $\mathrm{N}$ concentration than 2015. Multiple studies have reported positive or no effect of NI applied in fall on the ear leaf N concentration (Blackmer \& Sanchez, 1988; Boswell, 1977; Nash et al., 2013b; Touchton, Hoeft, \& Welch, 1979). Nitrapyrin added in fall with $67 \mathrm{~kg} \mathrm{~N}^{-1}$ as urea increased $\mathrm{N}$ concentration by $15 \%$ in the ear leaf when compared to urea without nitrapyrin (Touchton et al., 1979).

\subsubsection{Grain Moisture, Test Weight, and Yield}

Corn grain moisture of the fall $\mathrm{N}$ application was affected by the main effects of NI and year; however, the interaction between these factors was not significant (Table 4). Similar to chlorophyll meter readings and earleaf $\mathrm{N}$ concentration, grain moisture was not affected by the differences in application rates of pronitridine. Pronitridine at $18.7 \mathrm{~L} \mathrm{ha}^{-1}$ increased grain moisture 6.41 and $6.08 \mathrm{~g} \mathrm{~kg}^{-1}$ compared to nitrapyrin (NS) and AA with UAN, respectively. An increase in grain moisture with pronitridine might delay corn harvesting slightly and affect grain quality. No differences in grain moisture were observed between pronitridine at any rate and nitrapyrin (I). All NI treatments had greater grain moisture than the non-treated control except AA with UAN or nitrapyrin (NS). Grain test weight was affected by NI's and year, but no interaction was present (Table 4). All of the NI treatments and AA with UAN had 1.27 to $1.55 \mathrm{~kg} \mathrm{hL}^{-1}$ greater test weights than the non-treatment control treatment.

Corn grain yield was affected by the interaction between NI's and year for the fall $\mathrm{N}$ applications (Tables 4 and 6). Corn grain yields were greater in 2014 than 2015 for all treatments. The non-treated control had $7.44 \mathrm{Mg} \mathrm{ha}^{-1}$ greater yield in 2014 than 2015. Corn grain yield with all NI treatments was significantly higher than the non-treated control in both years. No significant differences were observed between NI treatments in 2014 which indicated that all NI's were equally efficient based on corn grain yield. An increase in the application rate of pronitridine from 9.4 to $28.1 \mathrm{~L} \mathrm{ha}^{-1}$ reduced corn grain yield $1.15 \mathrm{Mg} \mathrm{ha}^{-1}$ in 2015 which could be due to greater $\mathrm{N}$ remaining in the ammonium form. Pronitridine at $28.1 \mathrm{~L} \mathrm{ha}^{-1}$ reduced grain yield by 1.47 and $1.11 \mathrm{Mg} \mathrm{ha}^{-1}$ compared to nitrapyrin (I) and AA with UAN, respectively, in 2015. Use of nitrapyrin (I) increased corn grain yield $1.06 \mathrm{Mg} \mathrm{ha}^{-1}$ greater than nitrapyrin (NS) in 2015. Using pronitridine at $9.4 \mathrm{~L} \mathrm{ha}^{-1}$ with AA in fall during the low yielding year (2015) increased corn yield $0.74 \mathrm{Mg} \mathrm{ha}^{-1}$ compared to AA plus nitrapyrin (NS) (Table 6).

During a low yielding year like 2015, the anoxic conditions due to higher water availability early in the season may have caused abiotic stress to corn plants. A supplemental application of $\mathrm{N}$ is recommended when a plant suffers abiotic stress during a wet growing season. Adding higher rates of NI's during a wet year can result in reduced availability of $\mathrm{N}$ in soil to the corn plants (Hendrickson, Walsh, \& Keeney, 1978), which might result in a yield reduction. This can be the possible reason for lower corn grain yields with pronitridine when applied at higher rates compared to treatments that received pronitridine at lower rates in our study. In a study conducted by Blackmer and Sanchez (1988) in Iowa, a significant reduction in corn grain yield was observed when nitrapyrin was added to AA. The authors reported that nitrapyrin increased the susceptibility of plants to moisture stress and induced ammonia toxicity. To limit the yield losses due to NI's, an optimum combination of NI's application rate with $\mathrm{N}$ fertilizer is needed. In our study, pronitridine at $9.4 \mathrm{~L} \mathrm{ha}^{-1}$ with AA during 2015 increased corn yield compared to AA plus nitrapyrin (NS). The yield increase with pronitridine at $9.4 \mathrm{~L} \mathrm{ha}^{-1}$ could have also been due to a reduction in $\mathrm{N}$ loss via denitrification and timely availability of $\mathrm{N}$ to corn during the 2015 growing season.

\subsubsection{Corn Grain N Content, Removal, and Agronomic Efficiency}

Corn grain $\mathrm{N}$ content was significantly affected by the interaction between NI and year (Tables 4 and 6). All NI treatments had higher grain $\mathrm{N}$ content than the non-treated control in both years except nitrapyrin (NS or I) in 2015. No differences in grain N content were observed between NI treatments in 2014. In 2015, nitrapyrin (I) had 0.83 and $0.95 \mathrm{~g} \mathrm{~kg}^{-1}$ lower $\mathrm{N}$ content in the grain than AA with UAN and pronitridine at $18.7 \mathrm{~L} \mathrm{ha}^{-1}$, respectively. Grain N content in 2014 was greater than 2015 for all treatments. The non-treated control had 1.47 $\mathrm{g} \mathrm{kg}^{-1}$ more grain $\mathrm{N}$ content in 2014 than 2015. Grain $\mathrm{N}$ removal was greater with the use of all NI treatments compared to non-treated control (Table 7). Pronitridine at $18.7 \mathrm{~L} \mathrm{ha}^{-1}$ had 11.79 and $11.62 \mathrm{~g} \mathrm{~kg}^{-1}$ greater grain N removal than pronitridine at $28.1 \mathrm{~L} \mathrm{ha}^{-1}$ and nitrapyrin (NS), respectively (Table 7). Nitrapyrin (I) and AA with UAN were similar to pronitridine at any rate for grain $\mathrm{N}$ removal. Pronitridine at $28.1 \mathrm{~L} \mathrm{ha}^{-1} \mathrm{had}^{6.62}$ and 5.53 $\mathrm{kg} \mathrm{kg}^{-1}$ lower agronomic efficiency than pronitridine at $9.4 \mathrm{~L} \mathrm{ha}^{-1}$ and nitrapyrin (I), respectively. Nitrapyrin (NS) had $5.64 \mathrm{~kg} \mathrm{~kg}^{-1}$ lower agronomic efficiency than pronitridine at $9.4 \mathrm{~L} \mathrm{ha}^{-1}$. 
Table 7. Corn response to nitrification inhibitor with anhydrous ammonia when $\mathrm{N}$ amount was $112 \mathrm{~kg} \mathrm{~N}^{-1}(\alpha=$ $0.1)$. Results of significant nitrification inhibitor treatments

\begin{tabular}{|c|c|c|c|c|c|c|c|c|c|c|c|}
\hline \multirow{3}{*}{$\begin{array}{l}\text { Nitrification } \\
\text { Inhibitor }\end{array}$} & \multirow{3}{*}{$\begin{array}{l}\text { Application } \\
\text { Rates }\end{array}$} & \multicolumn{5}{|c|}{ Fall Application } & \multirow{2}{*}{\multicolumn{5}{|c|}{$\begin{array}{c}\text { Spring Application } \\
\text { Corn Grain Parameters }\end{array}$}} \\
\hline & & \multirow{2}{*}{ Grain Moisture } & \multirow{2}{*}{ Test Weight } & \multirow{2}{*}{$\begin{array}{l}\text { Grain } \\
\text { N removal }\end{array}$} & \multirow{2}{*}{$\begin{array}{l}\text { Agronomic } \\
\text { efficiency }\end{array}$} & \multirow{2}{*}{$\begin{array}{l}\text { Yield } \\
\text { increase }\end{array}$} & & & & & \\
\hline & & & & & & & Moisture & Yield & $\mathbf{N}$ & $\mathrm{N}$ removal & Starch \\
\hline & $\mathrm{L} \mathrm{ha}^{-1}$ & $\mathrm{~g} \mathrm{~kg}^{-1}$ & $\mathrm{~kg} \mathrm{hL}^{-1}$ & $\mathrm{~g} \mathrm{~kg}^{-1}$ & $\mathrm{~kg} \mathrm{~kg}^{-1}$ & $\%$ & $\mathrm{~g} \mathrm{~kg}^{-1}$ & $\mathrm{Mg} \mathrm{h}^{-1}$ & $\mathrm{~g} \mathrm{~kg}^{-1}$ & $\mathrm{~kg} \mathrm{ha}^{-1}$ & $\mathrm{~g} \mathrm{~kg}^{-1}$ \\
\hline Pronitridine & 9.4 & $173.42 \mathrm{ab}^{\S}$ & $71.88 \mathrm{a}$ & $160.30 \mathrm{ab}$ & $43.22 \mathrm{a}$ & $1.66 \mathrm{a}$ & $174.75 \mathrm{ab}$ & $13.53 \mathrm{ab}$ & $11.06 \mathrm{~b}$ & $153.61 \mathrm{a}$ & $738 \mathrm{~b}$ \\
\hline Pronitridine & 18.7 & $178.33 \mathrm{a}$ & $72.19 \mathrm{a}$ & $162.87 \mathrm{a}$ & $40.29 \mathrm{abc}$ & $-1.13 a b c$ & $181.75 \mathrm{a}$ & $13.30 \mathrm{ab}$ & $11.38 \mathrm{~b}$ & $155.11 \mathrm{a}$ & $735 \mathrm{~cd}$ \\
\hline Pronitridine & 28.1 & $174.25 \mathrm{ab}$ & $72.10 \mathrm{a}$ & $151.08 \mathrm{~b}$ & $36.60 \mathrm{c}$ & $-4.66 c$ & $169.67 \mathrm{cb}$ & $13.41 \mathrm{ab}$ & $11.36 \mathrm{~b}$ & $156.55 \mathrm{a}$ & $736 \mathrm{bcd}$ \\
\hline Nitrapyrin (NS) ${ }^{\dagger}$ & 2.3 & $171.92 \mathrm{bc}$ & $71.95 \mathrm{a}$ & $151.25 b$ & $37.58 \mathrm{bc}$ & $-3.63 b c$ & $175.83 \mathrm{ab}$ & $13.26 \mathrm{~b}$ & $11.6 \mathrm{ab}$ & $156.46 \mathrm{a}$ & $738 \mathrm{bc}$ \\
\hline Nitrapyrin (I) & 2.6 & $174.75 \mathrm{ab}$ & $72.23 \mathrm{a}$ & $155.97 \mathrm{ab}$ & $42.13 \mathrm{ab}$ & $1.17 \mathrm{ab}$ & $173.08 \mathrm{~b}$ & $13.91 \mathrm{a}$ & $11.46 \mathrm{ab}$ & $161.90 \mathrm{a}$ & $737 \mathrm{bcd}$ \\
\hline AA with UAN ${ }^{\ddagger}$ & & $172.25 \mathrm{bc}$ & $72.19 \mathrm{a}$ & $160.21 \mathrm{ab}$ & - & - & $177.25 \mathrm{ab}$ & $13.12 b$ & $11.95 \mathrm{a}$ & $160.00 \mathrm{a}$ & $734 d$ \\
\hline Non-treated Control & & $167.50 \mathrm{c}$ & $70.68 b$ & $90.72 \mathrm{c}$ & - & - & $163.00 \mathrm{c}$ & $9.36 \mathrm{c}$ & $9.63 \mathrm{c}$ & $93.83 \mathrm{~b}$ & $742 \mathrm{a}$ \\
\hline
\end{tabular}

Note. ${ }^{\dagger}$ Nitrapyrin was applied as N-serve (NS) or Instinct (I).

* UAN (32\%) is equivalent to $9.4 \mathrm{~L} \mathrm{ha}^{-1}$ Pronitridine.

${ }^{\S}$ Within a column and a given factor, means followed by the same letter are not statistically different $(\alpha=0.1)$.

" Yield increase for NI treatments was calculated by comparing NI treatments with that of AA with UAN.

Grain N content was reported to decrease when using nitrapyrin with AA by Hendrickson et al. (1978) whereas Boswell (1977) found no differences in grain N content for AA plus nitrapyrin when compared to non-treated AA in a three-year study. Tissue $\mathrm{N}$ content was lower in one out of three years of study for the AA only treatment compared to AA plus nitrapyrin (Boswell, 1977). Pronitridine and nitrapyrin used with UAN increased grain N removal and agronomic efficiency of corn in Missouri (Nelson, 2018).

\subsubsection{Corn Grain Quality}

The grain protein content was significantly higher in 2014 than 2015 for all treatments which was possibly due to wet conditions during the 2015 growing season. Grain protein content was greater with the use of all NI treatments compared to the non-treated control in 2014 and 2015 , except for pronitridine at $9.4 \mathrm{~L} \mathrm{ha}^{-1}$ in 2015 . Greater protein concentration in grain could be due to higher grain $\mathrm{N}$ concentration since $\mathrm{N}$ is a primary component of protein (Hay et al., 1953; Tsai et al., 1992). No significant differences in protein content between NI treatments were observed in 2014. In 2015, pronitridine at $9.4 \mathrm{~L} \mathrm{ha}^{-1}$ had $5 \mathrm{~g} \mathrm{~kg}^{-1}$ lower protein content than the pronitridine at $18.7 \mathrm{~L} \mathrm{ha}^{-1}$. Pronitridine at $9.4 \mathrm{~L} \mathrm{ha}^{-1}$ had 5 and $4 \mathrm{~g} \mathrm{~kg}^{-1}$ lower protein content than nitrapyrin (I) and AA with UAN in 2015.

In 2014, nitrapyrin (NS and I) and AA with UAN had $3 \mathrm{~g} \mathrm{~kg}^{-1}$ higher oil content in grain than pronitridine at 9.4 $\mathrm{L} \mathrm{ha}^{-1}$. No significant differences were found for oil content between the non-treated control and other NI treatments in 2014. In 2015, pronitridine at $9.4 \mathrm{~L} \mathrm{ha}^{-1}$ had 3 to $4 \mathrm{~g} \mathrm{~kg}^{-1}$ lower oil content than all other treatments including the non-treated control. Pronitridine at $9.4 \mathrm{~L} \mathrm{ha}^{-1}$ had $5.56 \mathrm{~g} \mathrm{~kg}^{-1}$ more oil content in grain in 2014 than 2015.

The non-treated control had higher grain starch content than all treatments except nitrapyrin (NS) and AA with UAN in 2014. Similarly, pronitridine at $9.4 \mathrm{~L} \mathrm{ha}^{-1}$ had a lower starch content than all treatments except pronitridine at $18.7 \mathrm{~L} \mathrm{ha}^{-1}$ in 2014. However, pronitridine at $9.4 \mathrm{~L} \mathrm{ha}^{-1}$ had higher starch content than all treatments except AA with UAN and non-treated control in 2015.

The grain starch concentration for pronitridine at 9.4, 18.7, and $28.1 \mathrm{~L} \mathrm{ha}^{-1}$ was 20, 9, and $7 \mathrm{~g} \mathrm{~kg}^{-1}$ less in 2014 than 2015, respectively. Similarly, AA with UAN had $8 \mathrm{~g} \mathrm{~kg}^{-1}$ more starch content in 2015 compared to 2014. No such differences between years were obtained for starch content for nitrapyrin (NS or I) and non-treated control treatments. Higher starch content in corn grain under waterlogged conditions compared to non-waterlogged soil conditions was also observed by Kaur et al. (2017) in claypan soils of Missouri.

\subsection{Spring $N$ Application}

\subsubsection{Chlorophyll Meter Readings}

Chlorophyll meter readings were greater in 2014 compared to 2015 for all treatments. The non-treated control had 13.65 SPAD unit's higher chlorophyll meter reading in 2014 than 2015. Chlorophyll meter readings for spring $\mathrm{N}$ application was significantly affected by the interaction between NI and year. All NI treatments had higher chlorophyll meter readings than the non-treated control each year. No differences were found between the 
NI treatments in 2014. However, AA with UAN, nitrapyrin (I), and pronitridine at $9.4 \mathrm{~L} \mathrm{ha}^{-1}$ had $3.92,4.22$, and 3.17 SPAD unit's higher chlorophyll meter readings in 2015 than pronitridine at $18.7 \mathrm{~L} \mathrm{ha}^{-1}$, respectively.

\subsubsection{Ear Leaf N Concentration}

Ear leaf N concentrations were greater in 2014 compared to 2015 for all treatments. The non-treated control had chlorophyll meter reading that was 13.65 SPAD units higher in 2014 than 2015. All treatments had higher ear leaf $\mathrm{N}$ concentrations compared to the non-treated control each year. Touchton et al. (1979) also reported 14\% higher ear leaf $\mathrm{N}$ concentration with spring $\mathrm{N}$ applications at $134 \mathrm{~kg} \mathrm{ha}^{-1}$ than the non-treated control. No differences were found between NI treatments in 2014. Nitrapyrin (I) and (NS) had 3.01 and $2.12 \mathrm{~g} \mathrm{~kg}^{-1} \mathrm{higher}$ ear leaf $\mathrm{N}$ concentration than pronitridine at $28.1 \mathrm{~L} \mathrm{ha}^{-1}$ in 2015 . Increasing the application rate of pronitridine did not increased ear leaf $\mathrm{N}$ concentration. In 2015, nitrapyrin (I) increased ear leaf $\mathrm{N}$ concentration $2.14 \mathrm{~g} \mathrm{~kg}^{-1}$ greater than AA with UAN. Nitrapyrin (I) inhibits the nitrification process and may have allowed prolonged availability of $\mathrm{N}$ to corn plants throughout the growing season compared to single pre-plant application of AA with UAN.

\subsubsection{Corn Grain Moisture and Yield}

Pronitridine at $18.7 \mathrm{~L} \mathrm{ha}^{-1}$ had 8.67 to $18.75 \mathrm{~g} \mathrm{~kg}^{-1}$ higher grain moisture than the pronitridine at $28.1 \mathrm{~L} \mathrm{ha}^{-1}$, nitrapyrin (I), and non-treated control. All NI treatments had 3.77 to $4.55 \mathrm{Mg} \mathrm{ha}^{-1}$ higher grain yield than the nontreated control. A consistent increase in corn yields with the use of NI's was presumably due to reduced nitrification rates and subsequently lower denitrification losses with the inhibitor (Nash et al., 2013b). Use of pronitridine at different rates provided similar yields as with nitrapyrin (NS) for spring $\mathrm{N}$ applications. However, no differences were obtained between the different rates of pronitridine when spring applied in this study. Nitrapyrin (I) had 0.65 to $4.55 \mathrm{Mg} \mathrm{ha}^{-1}$ greater yields than nitrapyrin (NS), AA with UAN, and the non-treated control, respectively.

\subsubsection{Corn Grain N Content and Removal}

Use of AA with UAN in spring had $2.32 \mathrm{~g} \mathrm{~kg}^{-1}$ higher grain $\mathrm{N}$ content than the non-treated control. Pronitridine at 9.4, 18.7, and $28.1 \mathrm{~L} \mathrm{ha}^{-1}$ had 0.57 to $0.89 \mathrm{~g} \mathrm{~kg}^{-1}$ lower grain $\mathrm{N}$ content than AA with UAN. Higher corn grain $\mathrm{N}$ content might have resulted from availability of more $\mathrm{N}$ for uptake by plants than in non-treated control that received no $\mathrm{N}$ applications or pronitridine treatments. All NI treatments resulted in 59.78 to $68.07 \mathrm{~kg} \mathrm{ha}^{-1}$ greater $\mathrm{N}$ removal than the non-treated control. In contrast, there was an $11 \%$ reduction in grain $\mathrm{N}$ concentration with nitrapyrin (NS) (Touchton et al., 1979). No significant differences were found between NI treatments in our research.

\subsubsection{Corn Grain Quality}

Grain protein content was significantly higher in 2014 than 2015 for all NI treatments except the non-treated control. A study conducted by Kaur et al. (2017) in the claypan soils reported that corn grain protein content was reduced with an increase in duration of waterlogged soil conditions. The same study reported that protein content of corn grain was reduced by $1.50 \mathrm{~g} \mathrm{~kg}^{-1}$ with each day of flooding (Kaur et al., 2017). Pronitridine applied at $18.7 \mathrm{~L} \mathrm{ha}^{-1}$ had 4 to $17 \mathrm{~g} \mathrm{~kg}^{-1}$ greater grain protein concentration than the nitrapyrin (NS and I) and non-treated control in 2014.The greater protein concentration could be due greater assimilation of $\mathrm{N}$ in the grain (Tsai et al., 1992). In 2015, both nitrapyrin (I) and AA with UAN increased protein content 5 to $10 \mathrm{~g} \mathrm{~kg}^{-1}$ compared to the non-treated control and pronitridine applied at $28.1 \mathrm{~L} \mathrm{ha}^{-1}$. The non-treated control had greater starch content than all other NI treatments. Pronitridine at $9.4 \mathrm{~L} \mathrm{ha}^{-1}$ had 3 to $4 \mathrm{~g} \mathrm{~kg}^{-1}$ greater starch content than pronitridine at 18.7 $\mathrm{L} \mathrm{ha}^{-1}$ and AA with UAN. Nitrapyrin (NS) had $3 \mathrm{~g} \mathrm{~kg}^{-1}$ higher grain starch concentration than AA with UAN Yearly differences in corn grain quality in response to different NI's used in this study might have occurred through variation in soil moisture and temperature conditions which affects the decomposition or dissolution of the NI's (Bronson, Mosier, \& Bishnoi, 1992; McCarty \& Bremner, 1989).

\section{Conclusion}

Our study indicates that the new NI pronitridine was effective in increasing corn grain yield in a low yielding year when rainfall received was $49 \%$ greater than the 10 -yr average. During a wet year, denitrification loss of $\mathrm{N}$ is higher and when supplemented with a NI like pronitridine may limit the denitrification loss and make N more available during the corn growing season. Additionally, pronitridine at $9.4 \mathrm{~L} \mathrm{ha}^{-1}+\mathrm{AA}$ applied in fall increased the agronomic efficiency $5.64 \mathrm{~kg} \mathrm{~kg}^{-1}$ compared to nitrapyrin (NS) + AA indicating that fall applied pronitridine + AA on claypan soil was a better option for farmer to add to AA for corn. In addition to the observed increased yield and agronomic efficiency, fall application of $\mathrm{N}$ generally saves money and time for farmers and increases efficiency of planting during spring. In this study, spring applied pronitridine + AA was as effective in increasing 
yield as compared to other NI's + AA. The greater benefit of using pronitridine as NI is the handling of the pronitridine compared to nitrapyrin. Pronitridine does not corrode the mixing tank and exposure to pronitridine is not classified as hazardous.

\section{Acknowledgements}

The authors would like to thank Lynn Bradley and Christopher Dudenhoeffer for their technical support and Koch Agronomic Services, LLC for their financial support of this research.

\section{References}

Abalos, D., Jeffery, S., Sanz-Cobena, A., Guardia, G., \& Vallejo, A. (2014). Meta-analysis of the effect of urease and nitrification inhibitors on crop productivity and nitrogen use efficiency. Agriculture, Ecosystems \& Environment, 189, 136-144. https://doi.org/10.1016/j.agee.2014.03.036

Abendroth, L. J., Elmore, R. W., Boyer, M. J., \& Marlay, S. K. (2011). Corn growth and development. PMR 1009 (p. 50). Ames, Iowa: Iowa State University Extension.

Aulakh, M., Rennie, D., \& Paul, E. (1984). Acetylene and N-serve effects upon $\mathrm{N}_{2} \mathrm{O}$ emissions from $\mathrm{NH}_{4}^{+}$and $\mathrm{NO}^{-}$treated soils under aerobic and anaerobic conditions. Soil Biology and Biochemistry, 16, 351-356. https://doi.org/10.1016/0038-0717(84)90031-2

Blackmer, A., \& Sanchez, C. (1988). Response of corn to nitrogen-15-labeled anhydrous ammonia with and without nitrapyrin in Iowa. Agronomy Journal, 80, 95-102. https://doi.org/10.2134/agronj1988.0002196200 $8000010022 x$

Boswell, F. C. (1977). Seasonal anhydrous ammonia comparison for corn with and without a nitrification inhibitor 1. Agronomy Journal, 69, 103-106. https://doi.org/10.2134/agronj1977.00021962006900010027x

Bronson, K., Mosier, A., \& Bishnoi, S. (1992). Nitrous oxide emissions in irrigated corn as affected by nitrification inhibitors. Soil Science Society of America Journal, 56, 161-165. https://doi.org/10.2136/ sssaj1992.03615995005600010025x

Burzaco, J. P., Ciampitti, I. A., \& Vyn, T. J. (2014). Nitrapyrin impacts on maize yield and nitrogen use efficiency with spring-applied nitrogen: Field studies vs. meta-analysis comparison. Agronomy Journal, 106, 753-760. https://doi.org/10.2134/agronj2013.0043

Cerrato, M., \& Blackmer, A. (1990). Effects of nitrapyrin on corn yields and recovery of ammonium-N at 18 site-years in Iowa. Journal of Production Agriculture, 3, 513-521. https://doi.org/10.2134/jpa1990.0513

Cook, R., Nail, A., Vigardt, A., Trlica, A., Hagarty, B., Williams, T., \& Wolt, J. (2015). Meta-analysis of enhanced efficiency fertilizers in corn systems in the Midwest. International Plant Nutritution Instute Report. Retrieved from http://research.ipni.net/project/IPNI-2014-USA-4RM06

Costa, C., Dwyer, L. M., Dutilleul, P., Stewart, D. W., Ma, B. L., \& Smith, D. L. (2001). Inter-relationships of applied nitrogen, spad, and yield of leafy and non-leafy maize genotypes. Journal of Plant Nutrition, 24, 1173-1194. https://doi.org/10.1081/PLN-100106974

Decock, C. (2014). Mitigating nitrous oxide emissions from corn cropping systems in the Midwestern US: Potential and data gaps. Environmental Science \& Technology, 48, 4247-4256. https://doi.org/10.1021/ es4055324

Fisk, L., Maccarone, L., Barton, L., \& Murphy, D. (2015). Nitrapyrin decreased nitrification of nitrogen released from soil organic matter but not amoA gene abundance at high soil temperature. Soil Biology and Biochemistry, 88, 214-223. https://doi.org/10.1016/j.soilbio.2015.05.029

Fixen, P., Brentrup, F., Bruulsema, T., Garcia, F., Norton, R., \& Zingore, S. (2015). Nutrient/fertilizer use efficiency: Measurement, current situation and trends. Managing water and fertilizer for sustainable agriculture intensification (pp. 1-30). Paris, France: IFA, IWMI, IPNI, and IPI.

Frame, W. (2017). Ammonia volatilization from urea treated with NBPT and two nitrification inhibitors. Agronomy Journal, 109, 378-387. https://doi.org/10.2134/agronj2016.08.0464

Gabrielson, K. D., \& Epling, M. L. (2016). Reaction products and methods for making and using same. US Patent No. 9,440,890 B2. Wichita, KS: Koch Agronomic Services, LLC.

Habibullah, H., Nelson, K., \& Motavalli, P. (2018). Management of nitrapyrin and pronitridine nitrification inhibitors with urea ammonium nitrate for winter wheat production. Agronomy, 8, 204. https://doi.org/ 10.3390/agronomy8100204 
Habibullah, H., Nelson, K. A., \& Motavalli, P. P. (2017). Assessing management of nitrapyrin with urea ammonium nitrate fertilizer on corn yield and soil nitrogen in a poorly-drained claypan soil. Journal of Agricultural Science, 9, 17. https://doi.org/10.5539/jas.v9n11p17

Hanson, R., Maledy, S., \& Jentes, C. (1987). Effect of anhydrous ammonia with and without nitrapyrin applied fall and spring on corn yield. Communications in Soil Science and Plant Analysis, 18, $387-403$. https://doi.org/10.1080/00103628709367828

Hay, R. E., Earley, E. B., \& DeTurk, E. E. (1953). Concentration and translocation of nitrogen compounds in the corn plant (Zea mays) during grain development. Plant Physiology, 28, 606-621. https://doi.org/10.1104/ pp.28.4.606

Hendrickson, L., Walsh, L., \& Keeney, D. (1978). Effectiveness of nitrapyrin in controlling nitrification of fall and spring-applied anhydrous ammonia. Agronomy Journal, 70, 704-708.

Kaur, G., Nelson, K., \& Motavalli, P. (2018). Early-season soil waterlogging and N fertilizer sources impacts on corn N uptake and apparent N recovery efficiency. Agronomy, 8, 102. https://doi.org/10.3390/agronomy 8070102

Kaur, G., Zurweller, B. A., Nelson, K. A., Motavalli, P. P., \& Dudenhoeffer, C. J. (2017). Soil waterlogging and nitrogen fertilizer management effects on corn and soybean yields. Agronomy Journal, 109, 97-106. https://doi.org/10.2134/agronj2016.07.0411

Kisaakye, E., Botwright T., Johnson, P., \& Shabala, S. (2015). Effect of water availability and nitrogen source on wheat growth and nitrogen-use efficiency. Proceedings of the 17th Australian Society of Agronomy Conference, Hobart, Australia (pp. 1-4).

Malhi, S., Grant, C., Johnston, A., \& Gill, K. (2001). Nitrogen fertilization management for no-till cereal production in the Canadian Great Plains: A review. Soil and Tillage Research, 60, 101-122. https://doi.org/10.1016/S0167-1987(01)00176-3

Markwell, J., Osterman J. C., \& Mitchell, J. L. (1995). Calibration of the Minolta SPAD-502 leaf chlorophyll meter. Photosynthesis research, 46, 467-472. https://doi.org/10.1007/BF00032301

McCarty, G., \& Bremner, J. (1989). Laboratory evaluation of dicyandiamide as a soil nitrification inhibitor. Communications in Soil Science and Plant Analysis, 20, 2049-2065. https://doi.org/10.1080/001036289 09368200

Nash, P. R., Nelson, K. A., \& Motavalli, P. P. (2013a). Corn yield response to polymer and non-coated urea placement and timings. International Journal of Plant Production, 7, 373-392.

Nash, P., Nelson, K., \& Motavalli, P. (2013b). Corn yield response to timing of strip-tillage and nitrogen source applications. Agronomy Journal, 105, 623-630. https://doi.org/10.2134/agronj2012.0338

Nash, P. R., Motavalli, P. P., \& Nelson, K. A. (2012). Nitrous oxide emissions from claypan soils due to nitrogen fertilizer source and tillage/fertilizer placement practices. Soil Science Society of America Journal, 76, 983-993. https://doi.org/10.2136/sssaj2011.0296

Nash, P. R., Motavalli, P. P., Nelson, K. A., \& Kremer, R. (2015). Ammonia and nitrous oxide gas loss with subsurface drainage and polymer-coated urea fertilizer in a poorly-drained soil. Journal of Soil and Water Conservation, 70, 267-275. https://doi.org/10.2489/jswc.70.4.267

Nathan, M., Stecker, J., \& Sun, Y. (2006). Soil testing in Missouri: A guide for conducting soil tests in Missouri (EC923). Columbia, MO: University of Missouri. Retrieved from http://soilplantlab.missouri.edu/ soil/ec923.pdf

Nelson, K. A. (2018). Pronitridine nitrification inhibitor with urea ammonium nitrate for corn. Journal of Agricultural Science, 10, 16-27. https://doi.org/10.5539/jas.v10n6p16

Nelson, K. A., Paniagua, S. M., \& Motavalli, P. P. (2009). Effect of polymer coated urea, irrigation, and drainage on nitrogen utilization and yield of corn in a claypan soil. Agronomy Journal, 101, 681-687. https://doi.org/10.2134/agronj2008.0201

Nelson, K. A., \& Smoot, R. L. (2012). Corn hybrid response to water management practices on claypan soil. International Journal of Agronomy, 2012, Article ID 925408. https://doi.org/10.1155/2012/925408 
Omonode, R. A., \& Vyn T. J. (2013). Nitrification kinetics and nitrous oxide emissions when nitrapyrin is coapplied with urea-ammonium nitrate. Agronomy Journal, 105, 1475-1486. https://doi.org/10.2134/ agronj2013.0184

Prasad, R. (1995). Nitrification inhibitors for agriculture, health, and the environment. Advances in Agronomy, 54, 233-281. https://doi.org/10.1016/S0065-2113(08)60901-3

Quemada, M., Baranski, M., Nobel-de Lange, M., Vallejo, A., \& Cooper, J. (2013). Meta-analysis of strategies to control nitrate leaching in irrigated agricultural systems and their effects on crop yield. Agriculture, Ecosystems \& Environment, 174, 1-10. https://doi.org/10.1016/j.agee.2013.04.018

Randall, G., \& Vetsch, J. (2005). Nitrate losses in subsurface drainage from a corn-soybean rotation as affected by fall and spring application of nitrogen and nitrapyrin. Journal of Environmental Quality, 34, 590-597. https://doi.org/10.2134/jeq2005.0590

Randall, G. W., Vetsch, J. A., \& Huffman, J. R. (2003). Corn production on a subsurface-drained mollisol as affected by time of nitrogen application and nitrapyrin. Agronomy Journal, 95, 1213-1219. https://doi.org/ 10.2134/agronj2003.1213

SAS Institute. (2014). SAS user's guide (V. 9.4). Cary, NC: SAS Inst.

Scharf, P. C., Brouder, S. M., \& Hoeft, R. G. (2006). Chlorophyll meter readings can predict nitrogen need and yield response of corn in the north-central USA. Agronomy Journal, 98, 655-665. https://doi.org/10.2134/ agronj2005.0070

Schepers, J., Francis D., Vigil M., \& Below F. (1992). Comparison of corn leaf nitrogen concentration and chlorophyll meter readings. Communications in Soil Science and Plant Analysis, 23, 2173-2187. https://doi.org/10.1080/00103629209368733

Stehouwer, R., \& Johnson, J. (1990). Urea and anhydrous ammonia management for conventional tillage corn production. Journal of Production Agriculture, 3, 507-513. https://doi.org/10.2134/jpa1990.0507

Touchton, J., Hoeft, R., \& Welch, L. (1979). Effect of nitrapyrin on nitrification of broadcast-applied urea, plant nutrient concentrations, and corn yield. Agronomy Journal, 71, 787-791. https://doi.org/10.2134/agronj1979. $00021962007100050019 x$

Tsai, C. Y., Dweikat, I., Huber, D. M., \& Warren, H. L. (1992). Interrelationship of nitrogen nutrition with maize (Zea mays) grain yield, nitrogen use efficiency and grain quality. Journal of the Science of Food and Agriculture, 58, 1-8. https://doi.org/10.1002/jsfa.2740580102

Vetsch, J. A., \& Randall, G. W. (2004). Corn production as affected by nitrogen application timing and tillage. Agronomy Journal, 96, 502-509.

Vetsch, J. A., \& Schwab, G. J. (2014). Corn Grain Yield as Affected by the Nitrification Inhibitor KAS771G77. Presented at the ASA, CSSA, \& SSSA International Annual Meeting. Retrieved from https://scisoc.confex. com/scisoc/2014am/webprogram/Paper86493.html

Waterhouse, H., Wade, J., Horwath, W. R., \& Burger, M. (2017). Effects of positively charged dicyandiamide and nitrogen fertilizer sources on nitrous oxide emissions in irrigated corn. Journal of Environmental Quality, 46, 1123-1130. https://doi.org/10.2134/jeq2017.01.0033

Wolt, J. D. (2004). A meta-evaluation of nitrapyrin agronomic and environmental effectiveness with emphasis on corn production in the Midwestern USA. Nutrient Cycling in Agroecosystems, 69, 23-41. https://doi.org/ 10.1023/B:FRES.0000025287.52565.99

\section{Copyrights}

Copyright for this article is retained by the author(s), with first publication rights granted to the journal.

This is an open-access article distributed under the terms and conditions of the Creative Commons Attribution license (http://creativecommons.org/licenses/by/4.0/). 